\title{
BENCANA SOSIAL KASUS LUMPUR PT. LAPINDO BRANTAS SIDOARJO, JAWA TIMUR
}

\author{
OLEH: \\ ELMAGHFIRA PUTRI ELIKA ${ }^{1}$, RISNA RESNAWATY², ARIE SURYA GUTAMA ${ }^{3}$ \\ 1. Mahasiswa Program Studi Sarjana (S-1) Kesejahteraan Sosial Fakultas Ilmu Sosial dan Ilmu Politik Universitas Padjadjaran \\ 2. Pusat Studi Kewirausahaan Sosial, CSR dan Pengembangan Masyarakat Fakultas Ilmu Sosial dan Ilmu Politik Universitas \\ Padjadjaran \\ 3. Departemen Kesejahteraan Sosial Fakultas Ilmu Sosial dan Ilmu Politik Universitas Padjadjaran
}

Email:

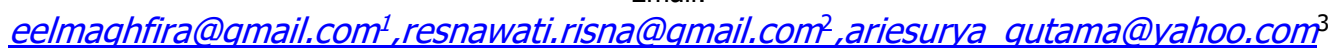

\begin{abstract}
This article explores the Lapindo Case not only as a physical disaster, but as a social disaster. The incident occured has threatened the people of Porong, Sidoarjo and also hit the East Java's economics and affected to the Indonesian development programs. There are not much articles in social science perspectives about this tragedy. This article is constructed Based on some of the information obtained, Sidoarjo in order to explore the, both high and low, political-economy aspects of the Lapindo Case. The author found that the destroyed public spaces, because of mudflow, had caused the damages of social sphe res, which lead to a serious social-political disaster. These facts has lead to multidimensional responses of the elite (the high politics) and the people (the low politics).
\end{abstract}

Key words: Lapindo Case, natural disaster, social disaster.

\section{PENDAHULUAN}

Tragedi Lumpur Lapindo dimulai pada tanggal 27 Mei 2006. Peristiwa ini menjadi suatu tragedi ketika banjir lumpur panas mulai menggenangi areal persawahan, pemukiman penduduk dan kawasan industri. Hal ini wajar mengingat volume lumpur diperkirakan sekitar 5.000 hingga 50 ribu meter kubik perhari (setara dengan muatan penuh 690 truk peti kemas berukuran besar). Akibatnya, semburan lumpur ini membawa dampak yang luar biasa bagi masyarakat sekitar maupun bagi aktivitas perekonomian di Jawa Timur:

1. Genangan hingga setinggi 6 meter pada pemukiman

2. Total warga yang dievakuasi lebih dari 8.200 jiwa.

3. Rumah/tempat tinggal yang rusak sebanyak 1.683 unit

4. Areal pertanian dan perkebunan rusak hingga lebih dari 200 ha 
5. Lebih dari 15 pabrik yang tergenang menghentikan aktivitas produksi dan merumahkan lebih dari 1.873 orang

6. Tidak berfungsinya sarana pendidikan

7. Kerusakan lingkungan wilayah yang tergenangi

8. Rusaknya sarana dan prasarana infrastruktur (jaringan listrik dan telepon)

9. Terhambatnya ruas jalan tol MalangSurabaya yang berakibat pula terhadap aktivitas produksi di kawasan Ngoro (Mojokerto) dan Pasuruan yang selama ini merupakan salah satu kawasan industri utama di Jawa Timur

Selain perusakan lingkungan dan gangguan kesehatan, dampak sosial banjir lumpur tidak bisa dipandang remeh. Setelah 28 lebih dari 100 hari tidak menunjukkan perbaikan kondisi, baik menyangkut kepedulian pemerintah, terganggunya pendidikan dan sumber penghasilan, ketidakpastian penyelesaian, dan tekanan psikis yang bertubi-tubi, krisis sosial mulai mengemuka. Perpecahan warga mulai muncul menyangkut biaya ganti rugi, teori konspirasi penyuapan oleh Lapindo,6 rebutan truk pembawa tanah urugan hingga penolakan menyangkut lokasi pembuangan lumpur setelah skenario penanganan teknis kebocoran 1 (menggunakan snubbing unit) dan 2 (pembuatan relief well) mengalami kegagalan. Akhirnya, yang muncul adalah konflik horisontal.

Setelah bertahun-tahun berjalan, bahkan hingga kini semburan itu tidak dapat dihentikan dan menjadi ancaman serius bagi orang-orang yang tinggal di sekitar wilayah itu. Tidak ada yang dapat memprediksi kapan semburan ini berhenti. Sampai saat ini, usaha pemerintah dan/atau Lapindo belum menunjukkan keberhasilan untuk menghentikan semburan ataupun mengelola dampak sosial dan lingkungan dari luberan lumpur itu (Schiller et al., 2008). Melihat bencana ini sebagai bencana kemanusiaan yang terkait dengan isu -isu pembangunan, negara, kapital dan ruang publik. Relasi pemerintah dan Lapindo cukup rumit, karena pemilik saham terbesar Lapindo adalah juga seorang menteri dalam periode 2004 -2009, Aburizal Bakrie. Wacana yang berkembang dalam kasus ini adalah adanya usaha menggunakan legitimasi kekuasaan dalam segala tindakan taktis pemerintah untuk menangani dampak pasca -bencana yang cenderung melindungi satu pihak dan menegasikan yang lain (Akbar, 2007).

Lumpur Panas Sidoarjo dalam Perspektif Ekonomi -Politik/Ekologi Oliver-Smith (1996) menguraikan tiga perspektif besar dalam studi antropologi bencana: (1) pendekatan respons yang cenderung melihat kerusakan dan bencana sebagai tantangan bagi struktur dan organisasi dalam masyarakat dan memfokuskan pada perilaku individual dan kelompok dalam berbagai macam tahapan pasca -bencana; (2) pendekatan perubahan sosial, yang melihat bencana sebagai faktor penting dalam perubahan sosial dan budaya, dalam arti bahwa bencana merusak atau menghancurkan kemampuan masyarakat untuk memenuhi kebutuhan anggotanya, penyesuaian baru harus segera disusun agar semua bisa berfungsi sebagaimana mestinya; 
dan (3) pendekatan ekonomi -politik/ekologi, yang mulai menyadari bencana bukan hanya masalah hasil dari perubahan geofisik seperti badai, gempa bumi, tanah longsor, banjir dan lain sebagainya, namun lebih melihat pada fungsi -fungsi tatanan sosial, struktur hubungan manusia dan alam, pada kerangka yang lebih besar, proses historis dan struktural, semacam kolonialisme dan kemiskinan, yang juga telah membentuk fenomena tersebut.

Dengan menggunakan perspektif ekonomi politik/ekologi dal am melihat Kasus Lapindo terbukalah kesempatan melakukan analisis lebih luas tentang fenomena itu, serta dampak materiil dan immateriil atas para korban langsung (Oliver-Smith, 2002), mengusulkan analisis variabel politik, ekonomi dan sosial dengan peristiwa alam tertentu untuk memahami penyebab-penyebab bencana dalam masyarakat dan lingkungannya. Artinya, kesadaran atas bencana dalam masyarakat menjadi relatif tergantung pada keberhasilan individu atau masyarakat untuk menyesuaikan diri pada alam.

Dalam tulisan ini ada empat aspek penting yang perlu digari sbawahi. Pertama, peristiwa, yaitu kejadian alam, dalam penelitian ini adalah luapan lumpur panas di Sidoarjo yang terjadi sejak 29 Mei 2006 hingga kini. Kedua, komunitas, dalam penelitian ini kelompok korban yang sebagian besar adalah warga kecamatan Porong, Sidoarjo. Ketiga, kerusakan dan/atau kehilangan fisik yang mengganggu rutinitas mereka. Tiga aspek ini muncul dalam kalimat pertama sebagai penegas bahwa bencana adalah sebuah objek yang bisa dan perlu dijelaskan oleh subjek (manusia). Lumpur panas adalah fenonema alam yang konkret ada secara fisik dan kehadirannya itu mengganggu fungsi -fungsi rutin dalam suatu komunitas, dan hal tersebut bisa disebut sebagai bencana.

Peran struktur sosial dan proses sosial dalam masyarakat pada suatu kondisi bencana, dapat dengan mudah terlihat dari kecepatan rekonstruksi masyarakat yang ter kena bencana. Dalam Kasus Lapindo, struktur sosial masyarakat ternyata tidak cukup kuat untuk menormalkan kembali kehidupan sosial dalam masyarakat. Negara sebagai salah satu contoh struktur sosial ternyata justru tidak bisa bersikap tegas terhadap perusah aan yang diduga menjadi sumber bencana ini, pun badan penanggulangan lumpur Sidoarjo (BPLS) yang dibentuk pemerintah untuk menangani bencana ini ternyata tidak bisa berjalan secara efektif (Muhtada, 2008).

Tentang proses sosial dalam bencana lumpur panas ini, ditemukan bahwa pada satu sisi bencana ini menjadi momentum yang mengikat solidaritas dalam masyarakat, yaitu pembentukan kelompok-kelompok sosial yang mengorganisir korban untuk mendapatkan kompensasi. Namun, pada sisi lain, bencana diyakini juga dapat memicu munculnya konflik sosial, yaitu terpecah-pecahnya masyarakat dalam kelompok -kelompok sosial (Abdullah, 2008).

\section{KONDISI SEBELUM LUMPUR MENYEMBUR}


Dalam artikel (Nino, 2010) Sejak krisis ekonomi 1997, turunnya Soeharto Mei 1998, dan mulainya era Reformasi telah mengubah iklim politik di Indonesia secara drastis. Di sektor pertambangan, Pemerintah Indonesia berada dalam posisi yang sulit ketika terpaksa mengubah regulasi tentang minyak bumi dan pertambangan mengikuti panduan-panduan dari International Monetary Fund (IMF). Dengan ditandatanganinya Undang -Undang Minyak dan Gas Bumi pada 2001, persaingan bebas industri minyak bumi dan mineral dimulai. Undang -undang ini membuka kesempatan bagi sektor swasta baik domestik maupun internasional untuk beroperasi di Indonesia, tanpa ada intervensi apapun dari pemerintah (Schiller et al., 2008).

UU sebelumnya mengatur bahwa pemerintah, melalui Pertamina, sebagai pihak yang berhak mengelola industri tambang demi kepentingan mensejahterakan rakyat. Perusahaan swasta waktu itu harus menandatangani perjanjian karya dengan Pertamina jika ingin melakukan kegiatan eksplorasi migas di wilayah Indonesia (Akbar, 2007:40 -3). Akibatnya, selama hampir separuh abad, Pertamina mendominasi industri minyak dan gas alam di Indonesia. Lahirnya UU baru meruntuhkan dominasi Pertamina. Pertamina, seperti layaknya perusahaan pertambangan yang lain, harus saling berkompetisi dengan perusahaan -perusahaan swasta domestik dan multinasional. Inilah latar belakang masuknya keluarga Bakrie dalam bisnis tambang. Jawa Timur memiliki cukup banyak titik eksplorasi migas yang dikelola oleh berbagai perusahaan domestik maupun asing seperti Energi Mega Persada (keluarga Bakrie),
Meta Epsi Drilling Company (kelompok Arifin Panigoro), Exxon Mobile (AS), Santos (Australia) dan Petronas (Malaysia).

Blok Brantas, yang melingkupi wilayah Sidoarjo, Mojokerto dan Pasuruan, merupakan salah satu lokasi eksplorasi migas. Pada awal 1990an, PT Huffco Brantas, perusahaan Amerika, memiliki kontrak perjanjian karya di blok Brantas. Pada pertengahan 1990an, Huffco menjual kontrak itu ke Lapindo Brantas Incorporated. Di tahun 2004, Energi Mega Persada (EMP) dan Novus Brantas ( British Petroleum) mengambil alih Lapindo. Pada tahun 2005, Novus Brantas menjual sahamnya ke Meta Epsi Drilling Company (Medco) dan Santos. Jadi komposisi kepemilikan Lapindo Brantas Inc. ketika lumpur mulai menyembur adalah: EMP (50 persen), Medco (32 persen) dan Santos (12 persen). EMP merupakan salah satu anak perusahaan Bakrie \& Brothers, menjelaskan keterlibatan Bakrie dalam eksplorasi migas di Sidoarjo.

Sebelum lumpur menyembur, Kabupaten Sidoarjo merupakan wilayah yang relatif stabil, ditunjukkan dengan minimnya gerakan sosialpolitik atau konflik skala besar di wilayah ini. Menurut catatan, kasus yang paling mengejutkan dan menjadi perhatian media nasional maupun internasional adalah kasus Marsinah, seorang buruh perempuan PT Maspion yang dibunuh karena aktivitas subversifnya dalam pengorgani sasian buruh.

Setelah kasus Marsinah nyaris tidak ada isu yang kontroversial dari Sidoarjo, sampai semburan lumpur itu terjadi. Sidoarjo terletak di sebelah Selatan Surabaya, ibukota provinsi Jawa Timur dan kota terbesar kedua di 
Indonesia setelah Jakarta . Karena itu, membicarakan Sidoarjo tak terlepas dari diskusi tentang interaksi antara Surabaya dan kawasan -kawasan pendukungnya (hinterlands). Jauh sebelum Belanda datang dan menjajah Indonesia, Surabaya (dan Pasuruan) telah dikenal dunia sebagai kota pel abuhan yang besar (Dick, 2002). Surabaya terletak di tengah kepulauan nusantara. Waktu itu, Batavia kini Jakarta belum ada apa -apanya, baru ketika pemerintah kolonial Belanda mulai masuk ke Indonesia, mereka memindahkan posisi strategis Surabaya ke Batavia . Posisi strategis Surabaya waktu itu membawa keuntungan bagi kawasan pendukungnya ( hinterlands), termasuk Sidoarjo. pelabuhan Surabaya, Tanjung Perak, merupakan pintu masuk sekaligus pintu keluar bagi barang -barang (goods) sebelum didistribusikan ke kota -kota lain di Jawa Timur, dan juga kawasan timur Indonesia. Untuk mendukung posisi Surabaya sebagai pintu utama keluar/masuknya komoditi pemerintah membangun dua kawasan industri besar di sekitar Surabaya: SIER ( Surabaya industrial estate Rungkut) di kawasan Surabaya selatan dan PIER (Pasuruan industrial estate Rembang) di Pasuruan sekitar 1,5 jam perjalanan ke selatan -timur Surabaya, melewati Sidoarjo. Pembangunan infrastruktur transportasi, seperti jalan tol, jalan raya, bandara dan terminal bus, mengarah pada usaha mendukung Sidoarjo sebagai kota satelit utama Surabaya. Bandar udara internasional Juanda yang terkenal sebagai bandara Surabaya terletak di wilayah Sidoarjo. Pemerintah Kabupaten Sidoarjo memanfaatkan keuntungan ini dengan mengelola jasa parkir dan monopoli bisnis taksi. Kondisi serupa juga terjadi pada terminal bus antar -kota Purabaya, yang kerap dikenal sebagai terminal Surabaya, juga berlokasi di wilayah Sidoarjo. Di era Presiden Megawati Soekarnoputri, Pemerintah Kota Surabaya, Pemerintah Ka bupaten Sidoarjo dan PT Kereta Api Indonesia (PT KAI) melakukan kerjasama untuk menyediakan jasa kereta komuter yang menghubungkan stasiun paling Utara di Surabaya (pasar Turi) dan stasiun paling Selatan di Sidoarjo (Porong). Susi, nama kereta itu, diresmikan oleh Presiden Megawati. Kereta komuter ini yang pertama yang menghubungkan Surabaya dan kota -kota satelitnya.

Proyek nasional jalan tol di Jawa Timur pun memulai pekerjaan dengan menghubungkan Surabaya dengan Gempol titik temu kota -kota di bagian Timur Jawa Timur (Pasuruan, Jember, dan Banyuwangi) dan Bali dengan kota -kota di daerah Selatan (Pandaan, Batu, dan Malang). Sidoarjo, yang terletak diantara Surabaya dan Gempol, juga kebagian efek pembangunan jalan tol itu, kemudahan transportasi menuju/dari $S$ urabaya. Jalan tol SurabayaGempol merupakan tulang punggung ( backbone) dari transportasi Jawa Timur, yang kemudian dipatahkan oleh luberan lumpur sehingga dampaknya sangat besar bagi perekonomian Jawa Timur.

Selain sistem transportasi, industri properti di Sidoarjo juga berkembang pesat dalam kurun waktu satu dekade terakhir. Pusat-pusat perbelanjaan baru dibuka (Ramayana dan Giant) dan taman bermain/hiburan juga dibangun untuk melayani kebutuhan penduduk 
Sidoarjo sehingga mereka tidak perlu pergi ke Surabaya. Akibatnya, semakin banyak orang memilih untuk tinggal dan menetap di Sidoarjo dibandingkan kota -kota satelit Surabaya lainnya (Gresik dan Bangkalan di utara atau Krian dan Mojokerto di barat). Selain mendukung Surabaya, Sidoarjo juga menjadi salah satu wilayah sasaran pada investor untuk mengembangkan usahanya. Pabrik -pabrik besar berdiri di kawasan jalan raya Buduran, Sidoarjo. Sidoarjo lalu berubah menjadi kota (town) dengan industri skala kecil sampai besar.

Akan tetapi, modernisasi-kapitalis yang merasuk di Sidoarjo harus berhadapan dengan realitas penduduk Sidoarjo yang masih bergantung pada sektor pertanian (padi dan tebu) dan perikanan (tambak). Karakter unik tanah di Sidoarjo adalah tambak untuk menanam segala jenis udang dan ikan (Bandeng, Kaka p, Gurami dan Patin) dan terdapat pengembangan jenis baru Kepiting Papua. Mates (2008) menyebutkan Sidoarjo sebagai penghasil udang terbesar kedua di Indonesia. Selain bertani udang, hasil industri kecil-menengah berkaitan dengan hasil tambak seperti krupuk dan terasi telah menjadi oleholeh khas dari Sidoarjo.

\section{LUMPUR TERUS MENGALIR}

Pada perkembangnya semburan lumpur tidak hanya terjadi pada satu titik. Pada September 2009 dilaporkan ada 98 titik semburan, yang mana se kitar lima puluh diantaranya masih aktif (Jakarta Post 11/09/2008). Pada artikelnya, Davies (2007) langsung mengkategorikan fenomena ini sebagai gunung lumpur, yang dipicu oleh aktivitas pengeboran yang menggunakan tekanan besar pada lapisan limestone. Gunung lumpur bukanlah kejadian baru di Jawa Timur, setidaknya ada dua gunung lumpur aktif: di Sangiran, Purwodadi (Davies, 2007; Mazzini 2007) dan Kalang Anyar (Davies, 2008). Mazzini (2007) memandang hipotesa Davies (2007), tentang semburan yang dipicu oleh aktivitas pengeboran, sebagai inconclusive. Kemudian, Mazzini mengangkat hipotesa semburan dipicu gempa bumi. Bantahan Mazzini itu dibantah kembali oleh Davies (2008) dengan menghadirkan kronologis pengeboran di sumur Banjar Panji.

Dalam kronologis itu dapat diketahui bahwa setelah mata bor mencapai kedalaman 1.091 meter Lapindo melanjutkan pengeboran tanpa menggunakan selubung pelindung ( casing) apapun. Pada 27 Mei, selang 10 menit setelah gempa mengguncang Yogyakarta -Jawa tengah pukul 06:02 WIB terjadi loss, masuknya lumpur ke dalam lubang pengeboran. Lapindo meneruskan pengeboran selama 6 jam sampai mencapai kedalaman 2.834 meter. Lapindo memutuskan untuk menghentikan pengeboran dan menarik mata bor ke permukaan tanah. Ketika bor sudah keluar semua, lumpur mulai mengalir dari lubang. Lapindo berusaha menutup lubang dengan semen dan berhasil. Lumpur tidak lagi keluar dari lubang pengeboran itu.

Esok harinya, 28 Mei, terjadi kick, cairan yang mengaliri seluruh lubang bor menendang lapisan tanah di seputar lubang pengeboran yang ternyata tidak cukup kuat menahan 
tekanan dari cairan itu. Akibatnya, lapisan tanah di sekeliling lubang pengeboran retak, dan cairan itu keluar dari retakan-retakan itu. Kejadian ini disebut sebagai blow out. Singkatnya, kondisi geologis di Sidoarjo dan sekitarnya potensial u ntuk terjadinya gunung lumpur mengingat ada beberapa gunung lumpur aktif saat ini, yang dibutuhkan adalah pemicunya. Akan tetapi, apapun penyebabnya, perdebatan para geolog itu berdampak pada kebijakan pemerintah dalam merespons dampak pasca -bencana. Kini, sudah lebih tiga tahun semburan itu tak kunjung juga berhenti. Semburan awal di tengah sawah mencapai ketinggian 40 -50 meter dari permukaan tanah. Setiap harinya, sekitar 7.000 - 150.000 meter kubik lumpur panas bersuhu 90 derajat celcius meluber ke permu kaan bumi. Untuk tujuan tidak mengakibatkan kepanikan masyarakat, terjadilah negosiasi internal perusahaan yang memutuskan untuk mempublikasikan angka 25.000 meter kubik per hari kepada media (Kompas 3/06/2006).

Masih menurut Kompas (19/06/2006), dalam waktu 21 hari saja lumpur sudah menutup sekitar 90 hektar kawasan persawahan, tambak dan perumahan. Dalam waktu satu bulan, luberan lumpur menutupi lebih kurang 200 hektar lahan (Kompas 17/07/2007). Sementara itu, Normile (2006) mencatat bahwa sampai September 2006, lumpur telah meluberi 240 hektar lahan; membanjiri desa -desa, pabrikpabrik, tambak udang dan sawah. Tiap hari semakin banyak bangunan (pabrik, sekolah, masjid, toko dan kantor pemerintahan) harus ditinggalkan karena banyaknya volume lumpur yang te rus keluar dari perut bumi. Sepuluh pabrik terpaksa menghentikan aktivitasnya (Kompas 19/6/2006), akibatnya lebih dari 1.873 buruh kehilangan pekerjaannya (Santoso, 2007). Ratusan hektar sawah menjadi tidak produktif, bukan hanya karena terendam lumpur tapi juga menutup saluran iigasi bagi sawah yang tak terendam lumpur. Lumpur juga menyerang tambak -tambak. Pada muara Sungai Porong, sedimentasi lumpur telah membentuk sebuah pulau kecil. Pada keadaan pasang di malam hari, "pulau" kecil itu menghalangi air pasang dari Selat Madura sehingga air laut masuk ke tambak -tambak yang dekat dengan bibir pantai. Akibatnya, ikan-ikan berenang ke laut dan hilang.

\section{MASYARAKAT TERUS MENUNTUT GANTI RUGI}

Konflik dalam masyarakat muncul karena perbedaan akses terhadap moda-moda produksi (modes of production). Di Porong, kecenderungan serupa muncul setelah lumpur mulai menenggelamkan sejumlah desa dan mengusir ribuan penduduk di sejumlah desa itu. Potensi konflik antar penduduk dimulai sejak lumpur membenamkan tempat tinggal mereka. Mereka harus mengungsi untuk sementara waktu, namun ketika itu belum terlintas sama sekali bahwa mereka harus pergi untuk selamanya. Mereka kehilangan harta miliknya yang terbenam dalam lumpur. Ketika gelombang pertama pengungsi mulai mengalir, waktu itu belum ada kejelasan siapakah yang harus bertanggung jawab atas penanganan pasca - luapan lumpur. Kondisi ini kemudian memunculkan ancaman bagi warga, karena 
tanah dan bangunan mereka sudah hilang sementara tidak ada yang bisa dimintai tanggungjawab. Warga pun mulai melakukan gerakan dengan menggelar demonstrasi dan protes. Mereka memblokade jalan, dan kadang rel kereta api. Beberapa kelompok jug a menolak dan memboikot pembangunan tanggul-tanggul baru. Menurut catatan Schiller et al. (2008), demonstrasi pertama terjadi pada pertengahan Agustus 2006 ketika para mantan pekerja, mayoritas perempuan, CV Surya Inti Perkasa, yang gedungnya terbenam lumpur, menuntut tanggung jawab Lapindo sebagai penyebab mereka kini menjadi pengangguran.

Di pertengahan September 2006, terjadi demonstrasi besar -besar pertama oleh penduduk. Mereka memaksa truk -truk Lapindo untuk membongkar muatannya, tanah dan batu, ke ruas jalan tol. Akibatnya, jalan tol tak bisa digunakan selama beberapa hari. Seminggu setelah ledakan pipa gas pertamina, 27 November 2006, para penduduk kembali menggelar aksi menutup jalan, kali ini aksi bertahan seminggu. Pada April 2007, sekelompok korban pergi ke Jakarta dan menemui Wakil Presiden Jusuf Kalla, sebelum akhirnya berhasil bertemu dengan Presiden Yudhoyono pada 24 Mei 2007, tiga hari sebelum peringatan setahun semburan lumpur panas. Dua bulan kemudian, sekitar 200 orang warga pergi ke Jakarta dan bertemu dengan Wakil Presiden Jusuf Kalla, Kepala BPLS Sunarso, dan anggota DPR. Mereka mempertanyakan tentang pembayaran ganti rugi yang belum segera dimulai. Mereka pun menggelar aksi di Jakarta.
Aksi terakhir ini, rupanya, cukup sukses karena berhasil memaksa Presiden Yudhoyono untuk berkunjung ke Sidoarjo selama tiga hari, 25-27 Juni 2006, untuk mengontrol langsung pembayaran ganti rugi, meskipun menurut beberapa warga, presiden tidak mengunjungi mereka yang tinggal di tempat pengungsian sementara di pasar baru Porong, dan hanya berkantor di kota Sidoarjo. Presiden memberikan batas akhir (deadline) pada Lapindo untuk membayar segala kewajibannya pada warga sebelum tanggal 14 September 2007. Sampai tanggal yang ditentukan ada 9.341 berkas yang sudah selesai dibayar 20 persen uang mukanya oleh Lapindo.

Meskipun potensi konflik cukup besar, namun rupanya ada penyebab lain yang mengurangi tidak terjadinya ketegangan dalam masyarakat, yaitu aspek geospasial. Setelah proses evakuasi, tidak semua penduduk mem ilih untuk tinggal di tempat pengungsian sementara, pasar baru Porong. Beberapa mereka menyewa rumah lain menggunakan uang yang didapat dari Lapindo. Lapindo membayar sejumlah 500 ribu rupiah uang pindah, lima juta rupiah untuk uang kontrak rumah selama dua tahun, dan 300 ribu rupiah/bulan/orang uang jatah hidup. Sesuai Peraturan Presiden 14/2007, Lapindo diharuskan membayar kewajiban membayar tanah dan bangunan warga, 20 persen di muka dan sisanya 80 persen sebelum kontrak rumah berakhir ( 2 tahun).

Pada awal mengungsi, tidak semua penduduk berhasil mendapatkan rumah sewa dengan jumlah uang yang didapatkannya dari Lapindo 
karena harga sewa rumah di Sidoarjo seketika melonjak tajam seiring dengan tingginya permintaan akan sewa rumah, sementara jumlah rumah pun terbatas. Membeli rumah baru pun tidak mungkin bagi sebagian besar warga. Mereka yang belum mendapatkan rumah pengganti memilih untuk tinggal di pasar baru Porong, sementara pada waktu yang bersamaan terus mencari tempat yang layak untuk dijadikan tempat tinggal baru. Ada juga warga yang memilih untuk tinggal di rumah keluarga dan/atau teman di Sidoarjo ataupun kota -kota lain (Surabaya, Malang, Pasuruan, Pandaan). Sebagian besar penduduk sekarang tinggal di tempat yang terpisah -pisah dari sebelumnya terlokalisir di satu area yang sama. Kondisi ini menyulitkan proses koordinasi dan pengorganisasian kelompok-kelompok warga. Untuk tujuan ini, masing -masing kelompok warga mendirikan posko tempat berkumpul jika mereka rapat dan mengorganisir sebuah kegiatan/aksi. Jarak yang jauh membuat hanya sebagian kecil penduduk yang bisa berkumpul di posko, sementara sebagian besar lainnya hanya menerima informasi dari mulut ke mulut. Konsekuensinya, kepentingan kelompok warga terkadang bukanlah murni mencerminkan kepentingan seluruh anggota, tapi hanya merupakan kepentingan para pengurus yang rutin mengadakan pertemuan, dan lainnya hanya mengikuti saja.

Pagar Rekorlap menunjukkan kondisi yang unik sebagai salah satu kelompok korban. Seluruh anggota kelompok Pagar Rekorlap b erasal dari desa yang sama, Renokenongo. Setelah terusir dari desanya, mereka memilih tinggal bersama di satu lokasi di pasar baru Porong. Mereka tidak hanya mendirikan posko yang mudah diakses oleh setiap anggotanya yang tinggal dalam area pasar, tapi mer eka juga menggunakan tempat berdoa (mushola) dan kamar mandi yang sama. Hal ini memudahkan kelompok ini untuk saling berkomunikasi dan berkoordinasi jika ada hal-hal penting yang mendesak untuk dibicarakan mereka cukup mengundang dari mulut ke mulut kemudi an berkumpul di posko. Inilah alasan Pagar Rekorlap terlihat lebih solid dibandingkan kelompok -kelompok korban lain.

Selain itu, mereka pun merencanakan agenda relokasi bersama; tidak tinggal di tempat yang terpisah-pisah, tapi secara kolektif membeli sep etak lahan dan berencana untuk tinggal bersama di lahan itu. Pada Juni 2009, Pagar Rekorlap telah meninggalkan Pasar Baru Porong dan mulai menempati lahan baru di Desa Kedungkampil. Untuk bisa membeli lahan yang cukup luas untuk menampung seluruh warga, me reka membutuhkan uang yang banyak, yang mereka harapkan akan didapatkan jika mereka menerima uang penjualan tanah dan bangunan mereka. Karena Lapindo tidak mengakui surat keterangan tanah yang dimiliki sebagian besar anggota kelompok, mereka pun berusaha $\mathrm{m}$ enemui dan meminta dukungan gubernur Jawa Timur Soekarwo untuk kemudahan mendapatkan sertifikat tanah dari kantor BPN Jawa Timur.

\section{METODE}

Metode yang digunakan dalam proses penelitian ini adalah studi literatur, yakni dalam proses penghimpunan data dan sumber - 
sumber yang berhubungan dengan topik yang dikaji didapat peneliti melalui berbagai sumber yakni seperti jurnal, buku dokumentasi, internet, maupun pustaka.

\section{KESIMPULAN}

Gunung lumpur di Porong telah mengakibatkan hilangnya public space yang berdampak pada terganggunya public sphere. Artikel ini melihat Kasus Lapindo sebagai sebuah bencana sosial yang artinya kerusakan yang terjadi bukanlah semata kerusakan fisik akibat luapan lumpur tapi pada gangguan-gangguan dalam sistem sosial masyarakat, bukan hanya komunitas lokal di Porong, tapi juga Pemerintah Pusat. Kerusakan fisik yang terjadi menjadi sebuah variabel yang menentukan respons-respons sosial-politis terhadap kerusakan fisik itu. Secara sederhana, tenggelamnya lahan -lahan produktif (bangunan, pekarangan dan sawah) telah mematikan produktivitas dari lahan-lahan tersebut.

Jika melihat secara lebih luas, terganggunya backbone sistem transportasi telah mengakibatkan kerugian -kerugian ekonomi pada sektor makro maupun mikro. Karena berhubungan dengan hajat hidup orang banyak maka kepentingan politis menjadi aspek yang memengaruhi respons berbagai pihak terhadap kasus ini. Salah satu usaha politis yang tampak adalah dalam hal penamaan kejadian ini. Politik penamaan atas kejadian ini merupakan sebuah tindakan politik yang melibatkan kuasa $\mathrm{p}$ ara aktor yang menggunakan masing-masing nama yang berbeda itu. Sebagai catatan tiap -tiap nama ("lumpur Lapindo", "lumpur Porong", "lumpur Sidoarjo", "lumpur panas") yang digunakan untuk peristiwa ini merepresentasikan perbedaan kepentingan para penggunany $a$, sehingga perbedaan nama bukanlah tidak berarti namun sangat diwarnai nuansa politik dari para aktor yang menggunakannya.

Sementara itu, luapan lumpur telah mengusik kemapanan roda pemerintahan nasional. Pemerintah pusat terpaksa turun tangan dalam menan gani dampak dari luapan lumpur yang tak belum dapat dihentikan itu. Akan tetapi, rupanya politik penanggulangan bencana yang diambil pemerintah pusat ternyata tidak serta merta menyelesaikan permasalahan sosial yang ditimbulkan akibat luapan lumpur ini, ba hkan justru cenderung menjadi pemicu bagi munculnya permasalahan-permasalahan sosial baik yang baru maupun yang tersembunyi. Dua regulasi tentang penanganan pasca -bencana lumpur ini menempatkan Lapindo Brantas pada posisi yang berbeda. Pada Peraturan Presi den 14/2007, Lapindo Brantas diwajibkan untuk membeli tanah dan bangunan warga di empat desa pertama (Maret 2007) yang sudah terbenam lumpur, sementara pada Peraturan Presiden 48/2008 tidak disebutkan nama Lapindo sebagai pihak yang berkewajiban membeli ta nah dan bangunan warga di tiga desa terdampak baru, semua biaya pembelian tanah dan bangunan warga dibebankan ke APBN. Peraturan Presiden tersebut telah memicu perpecahan dalam warga terdampak menjadi berbagai kelompok berdasarkan perbedaan kepentingan seb agai konsekuensi dari perbedaan kepemilikan atas status tanah. Ada warga yang dengan mudah menjual tanah 
dan bangunannya karena memiliki sertifikat tanah, sementara ada warga yang tidak berhak menjual tanah dan bangunan karena hanya memiliki surat keterang an tanah. Sementara itu, ada warga yang tidak berhak mendapatkan ganti rugi karena wilayahnya tidak masuk dalam Peta Area Terdampak yang terlampir dalam Peraturan Presiden tersebut. Para warga dari dua kelompok terakhir ini merasa tidak terima dengan statu s hukum (politik) yang ditimpakan pada mereka dan berusaha keras untuk mendapatkan ganti rugi sesuai harta miliknya yang musnah ditelan lumpur. Artinya, penentuan siapa korban dan siapa bukan korban dalam tragedi ini ditentukan oleh keputusan politik pemer intah pusat, tidak melihat pada kondisi faktual di Porong.

Pada level politik akar rumput ( grassroot), warga yang tidak puas dengan keputusan politik juga melakukan tindakan-tindakan politis dengan menyuarakan pendapatnya melalui berbagai macam aksi sosial, seperti demonstrasi sampai ke Jakarta, menemui presiden, wakil presiden dan anggota DPR, memblokir jalan dan rel kereta api. Tindakan ini merupakan media alternatif bagi para korban untuk mengekspresikan keprihatinan mereka pada masyarakat luas, tujuan politisnya jelas yaitu: bencana ini bukan semata bencana para warga di Porong saja tapi juga bencana bagi semua orang Indonesia. Mulanya, energi warga masih cukup besar untuk resisten terhadap Peraturan Presiden, namun seiring dengan pemenuhan kebutuhan dasar warga yang tak bisa ditolak seiring dengan berjalannya waktu, ditambah dengan tidak jelasnya posisi negara dalam memenuhi tuntutan warga itu, beberapa warga akhirnya 'mengalah' pada Peraturan Presiden yang sudah ditandatangani. Meskipun begitu, hampir seluruh gerakan politis yang dilakukan oleh warga mengarah pada masalah ganti -rugi terhadap tanah dan bangunan yang rusak akibat luapan lumpur, dan tidak melihat pada problem rehabilitasi ekologis di Porong. Jadi dalam Kasus Lapindo, sifat individualis melindungi hak milik sendiri-sendiri-lebih dominan mengendalikan warga terdampak ketimbang sifat kolektif-melakukan rehabilitasi ekologis di Porong.

Luapan lumpur panas telah menimbun ratusan hektar lahan, menyebabkan ribuan penduduk terpaksa mengungsi, memuku I ekonomi Jawa Timur, dan mempengaruhi dinamika politik pemerintah pusat. Hingga kini, tidak ada kepastian tentang kapan semburan itu akan berhenti, luapan lumpur itu menjadi ancaman yang menteror siapapun yang tinggal di sekitar wilayah itu. Menjadi jelaslah bahwa Kasus Lapindo ini bukanlah semata masalah kerusakan fisik yang ditimbulkan akibat lumpur yang terus meluap itu, melainkan juga bencana sosial karena bentukan dari struktur dan proses sosial -politik dalam masyarakat sebagai konsekuensi dari kehancuran ruang-ruang fisik itu. Oleh karenanya, dalam kajian -kajian tentang Kasus Lapindo perlulah memasukkan beberapa variabel seperti: budaya, kemiskinan, status sosial, struktur politik, dinamika sosial, dan variabel lainnya, sebagai pisau analisa agar bisa memberikan penjelasan yang lebih variatif dan detail tentang kasus ini. 


\section{UCAPAN TERIMAKASIH}

Tidak lupa penulis juga mengucapkan terimakasih kepada pihak - pihak yang membantu kelancaran penyusunan artikel ini:

1. Orangtua penulis yang senantiasa memberikan semangat dan dukungannya;

2. Risna Resnawaty, S.Sos., M.SI selaku dosen pembimbing yang senantiasa memberikan masukan dan semangat penulis agar dapat menyelesaikan tugas ini dengan baik;

3. Arie Surya Gutama, Sos., SE.,MM selaku dosen pembimbing yang senantiasa memberikan masukan dan semangat penulis agar dapat menyelesaikan tugas ini dengan baik;

4. Dosen Mata Kuliah Penelitian Pekerjaan Sosial;

5. Teman-teman yang selalu setia membantu dalam hal mengumpulkan data-data dalam pembuatan artikel ini;

\section{DAFTAR PUSTAKA}

Davies, R, Swarbrick, RE, Evans, RJ \& Huuse, M (2007) Birth of a mud volcano: East Java. GSA Today, 29 May, p.4-9

Kompas (3/06/2006), Sudah sepekan gas ganggu warga.

Kompas (19/06/2006), Pabrik terkubur, buruh menganggur.

Kompas (17/07/2007), Pembangunan kolam lumpur terhenti.

Peraturan Presiden No. 14 Tahun 2007 tentang Badan Penanggulangan Lumpur di Sidoarjo.

Peraturan Presiden No. 48 Tahun 2008 tentang Perubahan Atas Peraturan Presiden No.
14 Tahun 2007 tentang Badang

Penanggulangan Lumpur Sidoarjo.

Raharjo, ST. 2015. Assessment untuk Praktik Pekerjaan Sosial dan Kesejahteraan Sosial. Bandung: Unpad Press

2015. Dasar Pengetahuan Pekerjaan Sosial. Bandung: Unpad Press. 2015. Keterampilan Pekerjaan Sosial: Dasar-dasar. Bandung, Unpad Press.

Santoso, V (2007) Harga Industrialisasi Sektor Migas. Semburan Lumpur Lapindo sebagai Potret Kelemahan Negara dalam Menghadap Korporasi Ekstraktif Hidrokarbon. CSR Review:4-9.

Suryandaru, YS (2009) Kasus Lumpur Lapindo dalam Bingkai Media Massa. Surabaya: LPPM Unair \& TIFA Foundation.

Tempo (3 Maret 2008), Lumpur meluap, f ulus mengucur.

Wibisono, Yusuf. 2007. Membedah Konsep \& Aplikasi CSR. Gresik: Fascho Publishing

Febrian, Riandasa. 2012. "Lapindo Brantas". Diakses pada 20 Desember 2016. Diunduh dari https://accounting1st.wordpress.com/ 2012/07/07/lapindo-brantas-/

Situs resmi Badan Nasional Penangulangan Bencana. 2016. Diakses pada 2 April $2017 . \quad$ Diunduh dari https://www.bnpb.go.id/home/definisi 